\title{
MEMEDIASI NILAI-NILAI LUHUR BUDAYA MALUKU MASA LAMPAU
}

\section{Wayan Suantika}

\section{PENDAHULUAN.}

Dari kegiatan penelitian arkeologi yang telah dilaksanakan para akhli arkeologi di berbagai belahan dunia ini, dapat diketahui bahwa ilmu arkeologi yang mempelajari manusia dan kebudayaannya dimasa yang lampau, terbukti dapat memperpanjang sejarah kebudayaan umat manusia hingga jutaan tahun silam. Hal yang serupa juga kita hadapi di Indonesia, karena apabila kita hanya berpedoman pada berita sejarah semata, maka sejarah kebudayaan Indonesia sangatlah singkat, kerena berita tentang sejarah kehidupan manusia di bumi Nusantara sekitar abad IV masehi yakni sekitar 1600 tahun yang silam, yaitu dengan ditemukannya bukti-bukti tertulis yakni berupa yupa-yupa di daerah Kutai (Kalimantan) dan beberapa prasasti batu di daerah Jawa Barat.

Tetapi berdasarkan penelitian arkeologi yang telah dilaksanakan di beberapa tempat di Indonesia, telah berhasil ditemukan bukti-bukti adanya kehidupan manusia, dengan ditemukannya beberapa tulang / rangka manusia dan beberapa alat batu sehingga dapat disimpulkan bahwa kehidupan manusia dengan berbagai kebudayaannya telah ada dan berkembang jauh sebelum bangsa Indonesia memasuki era sejarah. Sebagai bukti dapat kita saksikan berupa fosil manusia purba yang ditemukan di Pulau Jawa, yang sering dikenal dengan sebutan Homo Erectus Javanicu, spesimen-spesimen pertama spesies ini telah ditemukan oleh Eugene Dubois di Kedungbrubus dan Trinil (Jawa Timur) antara tahun 1890 dan 1891 berupa mandibula (tulang paha) dari Kedungbrubus dan femur-femur ( tulang betis ) dari Trinil yang 
berasal dari endapan kabuh yang berusia Pletosen Tengah. Sedangkan alat-alat batu (artefak) yang disebut dengan serpih-bilah ditemukan di Sangiran disitus Ngebung, yang diperkirakan berasal dari Plestosen Atas (50.000 tahun) .

Jika kita cermati perkembangan kebudayaan Indonesia, maka dapat kita lihat adanya beragam peniggalan arkeologi yang tersebar diseluruh wilayah Nusantara. Semua tinggalan budaya tersebut adalah merupakan bukti outentik dari kemampuan cipta, karsa dan karya budaya leluhur bangsa Indonesia yang dapat dinyatakan sebagai akar budaya bangsa yang menjadikan bangsa Indonesia berkembang sampai saat ini. Sebagaimana diketahui peninggalan arkeologi sebagai bagian dari tingalan budaya ada yang berupa benda yang dapat dilihat dan diraba (Tangible), serta banyak pula yang tidak berupa benda, melainkan berupa gagasan atau ide (Intangible), akan tetapi semuanya memiliki nilai-nilai yang sangat penting dan berguna bagi kehidupan manusia. Sebagai karya budaya leluhur bangsa yang sangat beragam, peninggalan arkeologi ini dapat dipilah-pilah menurut bahannya, yaitu ada yang dibuat dari batu, kayu, tulang, tanah, kerang dan logam,tanduk dan lainnya. Di samping itu, pengamatan terhadap peningalan arkeologi dapat juga dilakukan menurut jamannya, yaitu ada yang berasal dari jaman prasejarah atau jaman pra Hindu-Budha, dengan tinggalan budaya berupa alat-alat dari batu, tulang, kayu, kerang, bangunan-bangunan megalitik (dolmen, menhir, sarkofagus, arca nenek moyang, bangunan teras berundak, tahta batu dan lainnya), benda-benda dari perunggu (nekara, gelang,anting-anting,kapak, tajak dan lainnya). (Soejono,1984). Sebagaian lagi ada yang dari jaman sejarah, ketika pengaruh Hindu-Budha telah meluas di seluruh Indonesia, yaitu berupa prasasti, candi-candi Hindu dan Budha, purapura kuno, arca-arca Hindu-Budha dan lainnya (Sumadio,1984; Kempers,1959). Pada masa berikutnya ada pula yang berasal dari masa berkembangnya pengaruh agama Islam (masjid kuno, nisan) dan juga dari masa pengaruh Barat (masa kolonial) dengan peninggalan berupa benteng, loji dan lainnya.

Kalau kita amati dengan seksama, maka dapat kita ketahui bahwa sejak jaman prasejarah keragaman budaya tersebut memang telah ada dan berkembang, serta diyakini telah memiliki nilai-nilai yang sangat penting bagi kehidupan manusia sejak dahulu dan beberapa di antara nilai-nilai tersebut masih sangat relevan dengan kehidupan manusia saat ini. Peninggalan arkeologi merupakan sumberdaya budaya yang memiliki berbagai nilai dan makna, antara lain nilai dan makna informasi / ilmu pengetahuan, ekonomi, estetika dan asosiasi simbolik (Cleere,1984).

Dengan latar pengertian seperti tersebut diatas, maka pada kesempatan ini ingin dicoba untuk mengedepankan berbagai tinggalan arkeologi yang terdapat di wilayah Maluku sebagai suatu bahan renungan untuk dapat nantinya dijadikan modal untuk meningkatkan rasa persatuan dan kesatuan masyarakat dalam menyongsong hari depan. Perlu dijelaskan bahwa wilayah Maluku yang dimaksud di sini meliputi daerah administratif Provinsi Maluku dan Maluku Utara sebagai sebuah satu kesatuan wilayah budaya.

Kenyataan menunjukkan kepada kita bahwa beberapa waktu yang lalu telah terjadi peristiwa kemanusiaan yang sangat menyedihkan di kota Ambon khususnya dan Maluku pada umumnya. Kehidupan masyarakat yang semula sangat aman tentram dan damai, tiba-tiba saja berubah menjadi suatu tragedi yang memilukan yang sama sekali tidak menampakkan nilai-nilai kemanusiaan dan sendi-sendi budaya yang semula telah melekat pada masyarakat Maluku yang sangat terkenal dengan konsep basudara (gandong) yang sangat terkenal itu. Maka pertanyaan yang patut dikedepankan adalah mengapa tragedi kemanusiaan tersebut sampai terjadi ?; Apakah konsep-konsep kebudayaan masyarakat Maluku yang luhur dan penuh persaudaraan tersebut sudah dlupakan?; Adakah faktor-faktor luaryang menyebabkan nilai-nilai luhur tersebut terabaikan? Untuk dapat menjawabnya tentu saja diperlukan penelitian yang lebih mendalam.

Terlepas dari itu, maka tujuan dari pada tulisan ini adalah mencoba untuk menampilkan kembali berbagai peninggalan budaya yang dimiliki oleh masyarakat Maluku, yang merupakan warisan dari nenek moyang, baik yang berupa benda-benda budaya maupun yang 
berupa nilai-nilai budaya, yang pernah ada dan berkembang sejak masa lampau hingga kini, serta yang lebih khusus lagi akan dicoba untuk mengedepankan peninggalan budaya yang memiliki nilai-nilai luhur yang pernah ada dan berkembang pada masyarakat Maluku masa lampau. Memediasi masa lampau dalam kesempatan ini dapat pula diberi makna menggali ( menemukan/ mengingat kembali); mengaktualisasikan dan merevitalisasikan nilai-nilai luhur Budaya Maluku masa lampau agar masyarakat dapat melangkah maju dengan berpijak pada akar budaya sendiri, sehingga tetap memiliki kepribadian dan jati diri, sesuai dengan dasar-dasar budaya yang telah dimiliki yang telah diakui memiliki esensi kemanusiaan dan rasa persatuan yang tinggi..

Dengan menampilkan berbagai wujud tinggalan arkeologi tersebut diharapkan masyarakat akan dapat lebih mengenal nilainilai luhur yang terkandung di dalamnya, sehingga dapat dijadikan pegangan dalam perjalanan menuju masa depan yang lebih maju dan sejahtera dalam suasana tentram dan damai.

\section{TINGGALAN ARKEOLOGI DI WILAYAH MALUKU}

Sebelum kita menuju pemaparan tentang tinggalan arkeologi yang ada di wilayah Maluku, marilah kita coba untuk lebih mendalami hubungan dan peran masa lampau bagi kehidupan kita masa kini dan masa yang akan datang. Manusia yang hidup dewasa ini memiliki sifat yang unik yaitu ingin mengetahui dan memahami kejadian-kejadian atau peristiwa masa lalu, karena masa lalu merupakan komponen penting dari kehidupan masa kini. Bahkan lebih jelas dikatakan bahwa keinginan/ dorongan untuk mengetahui masa lalu adalah hak azasi setiap manusia (Gimsey,1972).

Dari pernyataan tersebut dapatlah dipahami bahwa pengetahuan kita tentang masa lalu sangat penting dan sangat berguna bagi kehidupan masa kini dan masa yang akan datang. Ilmu arkeologi melalui benda-benda tinggalan budaya masa lalu mempelajari manusia dan kebudayaannya, cara-cara hidup dan memahami proses-proses budaya yang pernah terjadi, mempunyai keyakinan bahwa semua hal tersebut merupkan faktor penentu terbentuknya kepribadian suatu bangsa atau jati diri suatu bangsa. Oleh karena itu dikatakan bahwa kepribadian suatu bangsa tidak dapat secara mendadak dibentuk dari unsur-unsur masa kini saja. Kepribadian itu berurat dan berakar pada masa-masa yang sudah lewat, dan berkembang dari masa ke masa sejalan dengan sikap hidup yang dianut bangsa itu. Masa kini adalah akibat belaka dari perkembangan masa lalu, sedangkan masa depan akan berkembang berlandaskan usaha-usaha masa kini.

Oleh karena itu, nilai-nilai kehidupan dimasa lalu harus kita gali untuk menegakkan martabat kita sekarang, demi pembangunan masa depan. Mengingkari prestasi nenek moyang kita, berarti memalsu identitas kita sekarang, dan membangun atas dasar kepalsuan berarti menjerumuskan generasi yang akan datang (Soekmono,1982).

Dari uraian tersebut diatas, ada beberapa hal yang perlu kita perhatikan dan pertanyakan, berkaitan dengan kondisi bangsa yang kita alami baik yang berskala nasional maupun lokal. Jika diperhatikan beberapa tahun belakangan ini, utamanya sejak bergulirnya roda reformasi, perjalanan bangsa Indonesia telah diwarnai oleh berbagai problem yang sangat kompleks, diawali dengan krisis ekonomi, krisis kepercayaan, krisis moral hingga menjadi multi krisis yang melanda bangsa ini. Bahkan diperkirakan bangsa ini sedang mengalami dua proses disintegrasi yaitu vertikal dan horisontal, yang berarti ketahanan nasional sedang diuji. Ketahanan nasional adalah ketahanan budaya, ketahanan budaya adalah kemampuan bangsa ini mengelola keragaman budaya dari seluruh nusantara menjadi suatu kekuatan yang mampu mengangkat bangsa Indonesia setara dengan bangsa lain didunia. Sejak awal kebudayaan yang ada di Nusantara ini berasal dari satu dan mengalami perkembangan sejalan dengan kondisi alam lingkungan sekitarnya, sehingga pada akhirnya memunculkan keaneka ragaman. yang merupakan kekhususan dan keunikan sendiri dari setiap wilayah.

Provinsi Maluku dan Maluku Utara sebagai satu kesatuan wilayah budaya serta sebagai bagian dari wilayah Nusantara juga merupakan kawasan yang sangat kaya dengan peninggalan arkeologi baik yang 
berasal dari masa prasejarah, masa Klasik, masa Islam maupun masa kolonial. Dapat dipastikan semua peninggalan arkeologi tersebut memiliki nilai-nilai esensial dan penting yang telah mengantarkan masyarakat Maluku maju dan berkembang dari masa ke masa hingga sekarang ini. Dari hasil-hasil penelitian arkeologi yang telah dilaksanakan maka dapat diketahui bahwa, diwilayah ini terdapat banyak peninggalan arkeologi yang berasal dari berbagai masa budaya seperti :

Manusia yang menghuni kepulauan Maluku diperkirakan sudah ada sejak jaman pleistocen akhir (jaman es) sekitar 250.000 tahun yang lalu, dimulai dari kehidupan manusia yang paling sederhana, dimana manusia hidup masih berpindah-pindah dari satu tempat ketempat lainnya, berburu dan mengumpulkan makanan, hingga mencapai kehidupan yang lebih maju, yaitu hidup menetap dalam sebuah komunitas dan mengembangkan berbagai budidaya (domestikasi) berbagai jenis hewan dan melakukan kegiatan pertanian untuk memenuhi kebutuhan hidupnya. Kehidupan menetap dalam suatu tempat dan melakukan berbagai kegiatan secara bersama-sama adalah awal dari dikenalnya nilai-nilai kesatuan dan persatuan; rasa kebersamaan dan jiwa gotong-royong. Kehidupan menetap dalam suatu wilayah, dan mampu menyediakan sumber makanan disekitar wilayah tempat tinggal, menyebabkan terjadinya efisiensi energi, karena waktu dan tenaga tidak lagi dihabiskan untuk berburu dan hidup berpindah-pindah dan mengumpulkan makanan.

Dalam kondisi yang seperti ini mulai muncul ide-ide atau gagasan-gagasan untuk memenuhi kebutuhan jasmani dan rohani secara lebih mendalam. Masa ini adalah merupakan revolusi budaya dimana mulai dikenal adanya sistem nilai, yaitu adat-istiadat, kepercayaan, kemudian sistem sosial yaitu organisasi masyarakat, sopan-santun, kekerabatan, status sosial dan lainnya, dan tak kalah pentingnya pada masa ini banyak dihasilkan benda-budaya baik yang dibuat sendiri maupun yang diperoleh melalui cara-cara perdagangan kuno.

Bukti-bukti kebudayaan masa prasejarah yang telah ditemukan di wilayah Maluku antara lain: bekas hunian manusia purba dan batu perdamaian di pulau Kailolo dan Oma, Kecamatan Haruku, Maluku Tengah (Nendissa,1977), Lukisan pada dinding goa, cap tangan, gambar manusia dan gambar arah mata angin di situs Wamkana, Kecamatan Buru Selatan, Kabupaten Buru (Suryanto,1977); Batu meja pamali, batu meja marinyo dan batu asah parang di situs Ameth, Nusalaut, Kecamatan Saparua, Kabupaten Maluku Tengah. Fragmen nekara perunggu dan kubur purba ditemukan di Kei Kecil, Kabupaten Maluku Tenggara. Di situs Haria, Kecamatan Saparua, Maluku Tengah ditemukan Menhir, kursi batu, meja batu, dolmen dan jalan batu purba. Di situs Kamariang juga telah ditemukan beberapa buah dolmen (meja batu), batu pamali, batu tungku tiga (Sudarmika,2000). Pada situs Tanimbar Kei, Maluku Tenggara ditemukan struktur batu yang berfungsi sebagai pagar kampung (Sudarmika,2000). Di situs Jailolo, Lemola ditemukan dolmen; menhir dan lukisan goa (Sudarmika,2001), hal yang serupa juga ditemukan pada situs Sera dan Lolotuara, di Kecamatan Leti. Selain itu juga telah ditemukan beberapa buah Nekara perunggu yaitu di pulau Leti 3 buah; di Luang 1 buah; di pulau Tanimbar 1 buah dan di pulau Kei 3 buah (Niko \& Toos,1995). Dan tidak dapat dilupakan kampung Sangliatdol di Kecamatan Tanimbar adanya sebuah kampung yang memiliki pagar batu dengan bentuk perahu, yang dapat dipastikan merupakan penggambaran dari konsepkonsep pemikiran yang dimiliki oleh masyarakat pada masa itu.

Sedangkan tinggalan-tinggalan budaya yang berasal dari masa Hindu-Budha, berupa arca perwujudan dewi Parvathi dan arca perwujudan yang sampai saat ini disimpan di Museum Siwalima Ambon, serta situs, yang terletak Ohoivuur, Desa Letvuan, Kecamatan Kei Kecil, Kabupaten Maluku Tenggara yaitu berupa sisa-sisa pagar keliling dan adanya patung Kasdev dan Ditratngil yang dipercaya datang dari Bali dan telah berhasil mengembangkan sebuah peraturan atau norma kehidupan yang dikenal dengan hukum Larvul Ngabal .yang disepakati oleh pemimpin-pemimpin pada masa itu (Sahusilawane,1996a). Tembok batu yang serupa juga ditemukan di kampung Ohoiel, kecamatan Kei Besar. Dan ada informasi yang menyebutkan bahwa di lokasi tersebut tersimpan sebuah arca Ciwa 
Mahadewa (Sahusilawane,1996b) diyakini bahwa pemujaan dewa dan nenek moyang telah dilaksanakan oleh masyarakat pada masa itu.

Sedangkan tinggalan-tinggalan yang berasal dari masa masuk dan berkembangnya agama Islam dapat kita lihat seperti: peninggalan yang berupa Mesjid kuno, istana Sultan, makam-makam tokoh Islam, naskah-naskah kuno dan benda-benda lainnya. Contohnya antara lain dapat kita lihat seperti Mesjid Agung dan Istana Sultan yang masih berdiri megah di Ternate ( Ambary,1994). Mesjid 7 Pangkat dan makam tokoh Islam Maulana Ali Mahdun Ibrahim di desa Hitu Kaititu, Kecamatan Leihitu (Sahusilawane,1996c). Kemudian Mesjid kuno, makam kuno dan naskah-naskah kuno yang terdapat di Pulau Bacan (Ambary,1995). Serta masih banyak lagi tinggalan yang tersebar pada beberapa pulau yang terdapat di wilayah Maluku.

Sedangkan tinggalan-tinggalan yang berasal dari masa masuknya bangsa kulit putih atau yang sering disebut dengan masa kolonial adalah banyaknya peninggalan berupa bangunan benteng, loji,perk (rumah perkebunan) dan lainnya.

Sebagaimana kita ketahui bersama, bahwa kebudayaan ada yang berupa benda / memiliki fisik (tangible) dan ada juga yang berupa gagasan / nilai / ide tidak memiliki wujud / fisik (intangible). Tetapi dapat pula diyakini bahwa kebudayaan yang berwujud benda pasti diawali oleh sebuah ide / gagasan yang ada pada pikiran manusia pada masa itu, yang kemudian dengan kemampuan teknologi yang dikuasainya ide/gagasan tersebut dilahirkan / dibuat berupa bendabenda, yang kita kenal sebagai tinggalan arkeologi dan dapat kita temukan pada saat ini. Dengan demikian kajian terhadap tinggalantinggalan budaya pada masa lampau akan dapat mengetahui gagasangagasan cerdas yang dimiliki oleh masyarakat pada masa lalu yang dapat pula dipastikan menjadi pijakan yang berlangsung terus menerus hingga pada kehidupan kita dewasa ini. Masa lalu, masa kini dan masa yang akan datang adalah sebuah matarantai yang tidak dapat dipisahkan. Oleh karena itu sudah pada tempatnya kita mencoba untuk masuk dan menyelami kehidupan nenek moyang kita agar dapat kita mengetahui, memahami gagasan-gagasan cerdas yang mereka miliki.

\section{MEMEDIASI BUDAYA MALUKU MASA LALU.}

Dari semua paparan tersebut di atas, dapat kita ketahui satu hal yang amat penting yaitu bahwa manusia adalah makhluk yang paling cerdas dan paling tinggi akalnya, sehingga dapat belajar dari pengalaman hidupnya menuju adab yang lebih maju. Awal kehidupan manusia dimulai puluhan juta tahun silam diwarnai dengan permusuhan dan persaingan antar manusia sehingga mereka hidup terpencar-pencar dan menjauhkan diri satu dengan yang lainnya, karena setiap bertemu akan terjadi peperangan dan pembunuhan, sehingga lama-kelamaan mereka akan punah. Hidup dengan kelompok kecil sangat sulit untuk mempertahankan diri dari serangan lawan, sangat sulit untuk mencari dan mengumpulkan makanan dan kegiatan sehari-hari adalah mencari makanan dan hidup berpindah-pindah. Kondisi semacam ini telah menghabiskan energi mereka, sehingga kehidupan terasa statis dan tidak mengalami kemajuan yang berarti, demikian pula dengan usia harapan hidup menjadi sangat rendah, karena bayi yang baru lahir dan anak-anak selalu dibawa berpindah-pindah, sehingga sangat mudah terserang berbagai penyakit. Keadaan semacam ini tidak memberikan banyak waktu bagi mereka untuk berkembang.

Semua keadaan ini kemudian berubah setelah mereka mengenal konsep yang sekarang kita sebut dengan persatuan/kebersamaan. Masa berburu dan mengumpul makanan tingkat sederahana dan tingkat lanjut telah mereka tinggalkan, kemudian mereka mulai dengan kehidupan baru yaitu pola hidup menetap, yaitu bertempat tinggal bersama dalam suatu wilayah, dan membentuk hubungan kekeluargaan/kekerabatan, yang juga dibarengi dengan mulai adanya pembagian tugas.

Di kepulauan Maluku bukti-bukti adanya kehidupan menetap pada masa prasejarah ini diungkapkan oleh G.E.Rumphius (1705) yang menyebutkan telah ditemukannya alat-alat dari batu dan juga temuan Nekara perunggu. Kemudian disusul dengan berita penemuan lukisan-lukisan pada dinding goa batu karang yang ditemukan di desa Wamkana, Kecamatan Buru Selatan dan di desa Rumah Sokat Lama di Kecamatan Wahai, lukisan-lukisan itu ada berbentuk topeng, manusia menari, binatang melata, ikan, matahari, cap tangan, perahu 
dan sebagainya (Heekern,1972). Demikian juga lukisan-lukisan pada dinding goa yang ditemukan didesa Ohoidertawn, Kecamatan Kei Kecil, dimana ditemukan 4 buah goa yang pada dindingnya ditemukan lukisan-lukisan berupa telapak tangan, manusia menari, manusia berkelahi, manusia sedang duduk, topeng manusia dan gambar matahari, bahkan dengan warna merah dan kuning (Fadhlan,1996). Lukisan-lukisan pada goa-goa ini memberikan suatu petunjuk bahwa dalam suatu kehidupan bersama / dalam satu kesatuan yang paling sederhanapun, (hidup bersama dalam sebuah goa) telah dapat memotivasi, dapat memunculkan inovasi dan melahirkan berbagai kreasi yang dapat mengekspresikan kehidupan yang mereka jalani. Terlebih lagi setelah mereka mampu hidup bersama dalam sebuah bentang lahan yang mereka pilih sebagai tempat tinggal, maka dalam proses pemilihan tersebut mereka telah memperhatikan kemudahankemudahan sarana kehidupan seperti adanya sumber air, sumber makanan dan lainnya, pada akhirnya mereka dapat merealisasikan ide-ide yang ada pada pikiran mereka, sehingga akhirnya tatacara kehidupan dan pemikiran mereka semakin dinamis.

Perlu diketahui bahwa antara manusia dan ruang tempat tinggalnya terdapat banyak relasi, salah satu diantaranya nampak nyata dalam pemukiman manusia dan pola-pola yang dihasilkannya, baik pola tempat tinggal, pola pertanian serta berbagai religi yang mereka laksanakan. Pada periode bertempat tinggal menetap dan bercocok tanam ini, manusia mulai hidup menetap secara bersama-sama dalam suatu tempat, mulai mengenal berbagai ketentuan-ketentuan yang merupkan kesepakatan bersama, mulai ada pembagian kerja, yang akhirnya memunculkan berbagai bentuk keterampilan baik dalam bidang ideologi (gagasan), sosiologi (kemasyarakatan) maupun bidang teknologi (pembuatan alat kebutuhan hidup). Artinya kebudayaan manusia mengalami kemajuan yang sangat pesat pada masa ini. Hal ini dimungkinkan oleh karena mereka tidak lagi menghabiskan energinya untuk mencari dan mengumpulkan makanan semata, tetapi waktu dan harapan hidup meningkat karena telah ada pembagian tugas dalam suatu komunitas sehingga muncul dugaan mereka telah memiliki moto satu untuk semua dan semua untuk satu. Artinya dalam kelompok masyarakat tersebut telah muncul pemahaman pembagian tugas untuk kepentingan bersama, misalnya yang kuat dan muda bertugas berburu binatang, yang tua tinggal di rumah sambil membuat alat berbagai keperluan, wanita memasak dan menjaga anak-anak dan lain sebagainya, tetapi mereka mendapatkan hak yang sama. Nilai-nilai sopan santun, etika, mulai diterapkan sehingga kehidupan semakin tertib dan teratur.

Masa ini sering pula disebut dengan masa revolusi kebudayaan manusia, hal ini pasti juga terjadi terhadap masyarakat purba yang menghuni pulau-pulau yang ada di wilayah Maluku ini.

Revolusi kebudayaan manusia dibuktikan dengan munculnya berbagai gagasan manusia yang berkaitan dengan masalah-masalah kepercayaan / keyakinan, seperti kepercayaan adanya kehidupan didunia lain selain kehidupan sekarang. Kematian adalah suatu hal yang ada diluar jangkauan, maka dalam berbagai kebudayaan di dunia, peristiwa kematian berada pada satu posisi dan status yang sangat penting (Kuntjaraningrat,1979). Roh / arwah orang yang meninggal tetap hidup di alam yang lain, dan apabila diperlakukan dengan baik akan dapat memberikan perlindungan kepada keluarga/ kelompok yang ditinggalkan, sebaliknya akan dapat mencelakai / menyengsarakan mereka yang masih hidup apabila simati tidak diperlakukan dengan baik.

Konsep-konsep yang mendasari kebudayaan asli adalah adanya anggapan bahwa alam semesta didiami oleh makhluk-makhluk halus dan roh-roh. Selain itu alam dianggap mempunyai kekuatan yang melebihi kekuatan manusia (Adi Kodrati) (Kuntjaraningrat, 1958). Ide / pemikiran semacam ini merupakan dasar munculnya budaya penghormatan kepada leluhur yang telah meninggal, sehingga dibuatlah beragam bentuk dan variasi Patung Moyang sebagai sarana pemujaan tersebut. Pembuatan patung moyang ini jelas dilatari sifat religius magis, dilaksanakan dengan proses religi yang sakral, karena dikaitkan dengan adanya konsep kepercayaan tersebut di atas. Di beberapa tempat di Indonesia, seperti di Pulau timor, Pulau Kei, Pulau 
Seram dan Pulau Sumba, pemujaan terhadap dewa matahari masih tetap dilaksanakan, karena beberapa suku bangsa tersebut menganggap bahwa mereka adalah keturunan dari Dewa Matahari (Perry,1918).

Masyarakat yang mendiami wilayah Maluku pada masa yang lampau juga mengenal dan melaksanakan konsep kepercayaan kepada leluhur, sehingga melahirkan berbagai wujud patung moyang yang dapat kita saksikan sampai saat ini, seperti:

- Patung dewa khususnya Dewa Matahari (Upuleru); Dewi Bumi atau Bulan ( Upuina).

- Patung Moyang yang memanifestasikan orang-orang penting dalam suatu susunan kemasyarakatan, seperti: Raja, Dere dan Luli (pendiri kampung), jenis patung berupa: patung keluarga, patung persembahan, patung pelindung, patung moyang sebagai atribut kerajaan, patung simbolik magi destruktif (perahu doti), patung moyang sebagai media amulet. Beberapa dari bentuk patung tersebut sekarang tersimpan dan dipamerkan di Museum Siwa Lima Ambon (Rijoly,1989).

Benda-benda budaya lainnya yang ditinggalkan oleh adanya kepercayaan ini adapula berupa bangunan-bangunan pemujaan seperti: Menhir (batu tegak), Dolmen (meja batu), bangunan teras berundak, pagar kampung, dan lainnya, sangat terkait dengan berbagai kepercayaan yang ada dalam kehidupan masyarakat,yang merupakan dasar-dasar dari ikatan kebersamaan dan dasar gotong-royong dalam setiap langkah kehidupan mereka pada masa yang lampau.

Jika kita perhatikan dengan seksama, maka kebudayaan masyarakat yang mendiami seluruh wilayah Maluku, yang terdiri dari ribuan pulau, pada dasarnya memiliki lebih banyak persamaan dari pada perbedaan antara satu dengan lainnya, bahkan dapat dikatakan bahwa pada dasarnya konsep kehidupan meraka hampir sama, mungkin sedikit perbedaan itu muncul karena pengaruh dan kesediaan sarana dan prasarana yang ada pada lingkungan hidup sekitarnya. Bahkan dapat dikatakan bahwa konsep pemikiran yang mereka miliki terkait dengan religi, sosial masyarakat memiliki banyak kesamaan, tetapi perbedaan muncul karena perbedaan satrategi untuk beradaptasi dengan lingkungan alam sekitarnya. Semua konsep budaya dan tinggalan budaya dari masa prasejarah tersebut, akan berlanjut terus pada masa-masa berikutnya.

Terkait dengan masa budaya yang disebut denga periode klasik Hindu dan Budha, memang tidak banyak yang ditemukan di wilayah Maluku sampai dengan saat ini, tetapi dapat diperkirakan bahwa pengaruh budaya Hindu itu ada, seperti lahir dan diterapkannya hukum tradisional yang disebut dengan larvul ngabal dan pemujaan luluhur yang tentunya memiliki manfaat bagi kehidupan masyarakat, karena terlahir dari kesepakatan 7 kelompok masyarakat yang ada pada masa itu.

Dalam perkembangan budaya selanjutnya, maka masyarakat penghuni wilayah kepulauan Maluku menerima masuk dan berkembangnya agama Islam, yang pada intinya juga masih tetap melanjutkan tradisi-tradisi lama, ditambah dengan pemahaman terhadap ajaran agama islam, sehingga akhirnya memperkaya wawasan kebudayaan masyarakat Maluku sendiri, sehingga banyak meninggalkan bangunan pemujaan yaitu mesjid serta pemujaan terhadap tokoh-tokoh agama Islam terbukti dengan adanya makammakam kuno yang sampai saat ini masih di puja.

Memasuki masa kolonial, masyarakat Maluku kembali memperoleh pengaruh baru dan mengalami berbagai peristiwa yang meninggalkan berbagai kepedihan bagi masyarakat Maluku, karena rasa kebersamaan yang telah ada dipecah belah oleh bangsa kolonial. Meskipun jiwa bela negara dan heroisme yang tinggi ditujukkan dengan adanya berbagai peperangan dibeberapa daerah, tetap tidak berhasil karena rasa persatuan, kebersamaan dan sifat gotong-royong sudah terpecah belah dan tercerai berai. Banyaknya benteng-benteng pertahanan yang dibuat oleh bangsa kolonial menjadi bukti nyata betapa tingginya jiwa belanegara dan patriotisme masyarakat pada masa itu. 
Dari rangkaian panjang peristiwa sejarah kebudayaan masyarakat Maluku, yang sudah berlangsung lebih dari puluhan ribu tahun silam, maka dapat dipastikan banyak konsep-konsep kehidupan yang memiliki nilai-nilai luhur yang terlahir dan menjadi pedoman kehidupan masyarakat Maluku sejak dahulu hingga masa kini. Serta diyakini bahwa konsep dan nilai luhur tersebut masih banyak yang memiliki relevansi dengan kehidupan masa kini dan masa depan.

\section{NILAI-NILAI LUHUR BUDAYA MALUKU MASA \\ LAMPAU}

Menyaksikan berbagai tinggalan budaya yang dapat kita lihat sampai dengan dewasa ini, maka ada beberapa hal patut kita renungkan dan pahami berkaitan dengan nilai-nilai luhur yang dimiliki oleh pendahulu kita, sebagai dasar pijakan bagi kita yang hidup dewasa ini untuk dapat mengerti dan memahami serta memanfaatkan semua kekayaan budaya tersebut demi kemajuan adab dan kesejahteraan bersama. Peranan budaya masa lalu tidak dapat diabaikan manfaatnya bagi kehidupan masa kini dan masa yang akan datang.

Oleh karena itu pada kesempatan ini akan dicoba untuk menampilkan nilai-nilai luhur yang dapat dipetik dari keberadaan tinggalan budaya (budaya materi/tangible) serta konsep/gagasan budaya (budaya non materi/intangible) tersebut agar dapat menjadi bahan mediasi/ renungkan bagi masa depan Maluku yang lebih maju dan bersatu. Beberapa hal yang dapat kita petik dari perjalanan panjang sejarah kebudayaan masyarakat Maluku tersebut antara lain:

\section{Konsep persatuan dan kesatuan.}

Pembuatan/pendirian bangunan-bangunan yang bersifat sakral maupun profan pada masa yang lalu, seperti: Menhir, Dolmen (Meja batu), Punden berundak, tembok keliling desa (dwala) dan lainnya ( Masa Prasejarah). Bangunan Mesjid, Makam kuno, Baileo/rumah adat (Masa Islam), memberikan suatu bukti bahwa jiwa kesatuan dan persatuan; rasa kebersamaan, jiwa Gotong royong ( yang dikenal dengan konsep Masohi, Pela dan Gandong) adalah bukti tingginya nilai-nilai kebersamaan tersebut. Karena kita meyakini suatu kegiatan pembangunan memerlukan banyak tenaga manusia, karena harus diawali dengan mencari, mengumpulkan, mengangkut / memindahkan dan menusun berbagai material bangunan yang dipergunakan,seperti batu,kayu, bahan atap dan lainnya, yang berasal dari tempat yag jauh dan dalam jumlah yang cukup banyak. Artinya pekerjaan ini hanya dapat dilaksanakan dengan adanya rasa persatuan dan kesatuan, kebersamaan serata jiwa gotong-royong yang tinggi.

\section{Konsep kepercayaan terhadap Tuhan Yang Maha Esa.}

Banyaknya tinggalan budaya yang berupa bangunan pemujaan ( Menhir, Dolmen/batu meja, teras berundak dan lainnya) dan banyaknya jenis patung-patung pemujaan, Bangunan Mesjid Kuna, Makam Kuna ( Tokoh Agama); Gereja kuna. Keberdaaan bangunanbangunan pemujaan ini memberikan makna yang tidak terbantahkan bahwa sejak jaman dahulu hingga masa kini masyarakat Maluku adalah masyarakat yang memiliki sifat religiusmagis, sehingga dalam kehidupan kesehariannya selalu mengutamakan keharmoniasan hubungan dengan alam sekitarnya dan utamanya Tuhan Pencipta Semesta Alam ini. Konsep semacam ini dapat dikatakan sebagai sebuah kecerdasan lokal ( local genius). Dengan demikian Konsep kepercayaan dan Pemujaan Terhadap Tuhan Yang Maha Esa serta rasa hormat terhadap leluhur/nenek moyang adalah nilai luhur yang sangat penting untuk diketahui dan dikenal oleh masyarakat dewasa ini.

\section{Konsep kemanusiaan.}

Kehidupan manusia yang diawali dengan berbagai peperangan, yang didasari dengan hukum rimba yang artinya jiwa manusia dan rasa kemanusiaan belum dikenal atau terabaikan, pada akhirnya mulai mendapatkan perhatian. Lahir, hidup dan mati mulai mendapatkan berbagai perlakuan khusus yang dikenal dengan adanya berbagai bentuk upacara sejak lahir hingga mati. Adanya kepercayaan yang kemudian disusul dengan masuknya agama, pada dasarnya semakin menguatkan dan meningkatkan rasa kemanusiaan, seiring dengan lahirnya berbagai aturan dan norma adat dan agama. Konsep-konsep 
yang dikenal seperti: Sapa mau biar dia pung garang malele, ( Tidak seorangpun akan membiarkan sanak familinya dihina). Juga ada ungkapan It besa wu-it ain mehe ni ngifun, manut ain mehe ni tilur.( Kami adalah telur-telur ikan yang berasal dari seekor induk ikan, atau telur-telur ayam dari seekor induk ayam) ungkapan ini mencermikan rasa persamaan derajat sesama manusia dan merupakan pehaman nilai-nilai Kemanusian yang paling hakiki.

\section{Konsep kearifan atas lingkungan.}

Kepercayaan akan adanya kekuatan supernatural dan kehidupan abadi rokh / arwah nenek moyang, serta interakasi manusia dengan lingkungannya, bila kita cermati ternyata memiliki berbagai pemikiran yang terkait dengan kelestarian lingkungan hidup, yang dapat dikatakan sebagai suatu kearifan dari masyarakat masa lampau yang pernah mendiami kepulauan Maluku. Kepercayaan bahawa ada kekuatan yang maha dahsyat di luar kemampuan manusia serta keyakinan bahwa arwah / roh nenek moyang berada di sekitar kita, menempati puncak bukit / gunung atau pada pohon-pohon yang besar. Berbagai konsep kepercayaan ini menyebabkan masyarakat selalu menjaga keharmonisan dengan lingkungannya seperti : Tidak sembarangan menebang pohon; Tidak mengeksploitasi hutan; Manusia berusaha memelihara lingkungan hidup sekitarnya; Tidak ada keinginan untuk menguasai dan mengalahkan lingkungan. Itulah sebabnya mengapa lingkungan terjaga dengan baik.

5. Konsep belanegara atau patriotisme.

Berdirinya benteng-benteng pertahanan pada hampir setiap pulau di wilayah Maluku, didirikan oleh para kolonialis dari barat, memberikan suatu bukti bahwa setelah masyarakat Maluku menyadari bahwa penjajahan dengan berkedok perdagangan, mulailah mereka mengadakan perlawanan hampir di setiap daerah untuk mempertahankan hak azasi mereka. Tingginya semangat patriotisme ini tentu saja menjadi kurang efektif, karena perjuangan masih bersifat parsial kedaerahan, karena terjadi pada wilayah-wilayah tertentu dan belum terkoordinasi dalam satu kesatuan aksi perlawanan yang menyeluruh. Namun sebagai sebuah tatanan nilai dalam suatu komunitas masyarakat, nilai-nilai patriotisme ini perlu mendapatkan perhatian untuk dipupuk dan dipelihara serta ditingkatkan dewasa ini, sehingga penjajahan yang serupa tidak terjadi lagi pada masa yang akan datang.

Demikianlah beberapa konsep / nilai yang dapat kita petik dari adanya perjalanan sejarah kebudayaan manusia yang pernah ada dan menetap dikepulauan Maluku yang kita cintai ini. Selain yang dapat kita petik dari kajian benda-benda budaya dalam wujud fisik (tangible), dari tatanan nilai-nilai budaya yang pernah berlaku sejak masa lalu hingga masa kini juga dapat kita petik hal-hal yang masih relevan, seperti istilah Siwa-Lima; Pela; Gandong; Potong di kuku rasa di daging; Mari hiti-hiti hala-hala; Dan masih banyak lagi yang lainnya yang sangat berguna dan bermanfaat.

\section{KESIMPULAN DAN SARAN-SARAN.}

\section{Kesimpulan.}

Dari keseluruhan uraian yang telah paparkan dalam tulisan ini, maka dengan sangat meyakinkan dapat kita katakan bahwa sejarah kebudayaan manusia yang pernah hidup bertempat tinggal dan berkembang di wilayah Maluku ini, adalah merupakan masyarakat yang sangat dinamis dan telah bergaul dengan orang-orang yang datang dari luar pulau,serta memiliki local genius (karakter lokal) sehingga bisa beradaptasi dengan budaya luar yang datang, tetapi tidak pernah kehilangan karakternya yang khas. Oleh karena itu dapat disimpulkan hal-hal sebagai berikut :

- Masyarakat yang mendiami wilayah Maluku,yang sudah berabadabad lamanya telah memberikan warisan berupa local genius / karakter khas yang dimiliki oleh masyarakat yang ada sekarang ini, dan sangat penting untuk diketahui dan dipahami.

- Tinggalan arkeologi dan berbagai konsep luhur yang dapat dipetik dari perkembangan manusia dan kebudayaan masa lampau adalah adanya kesadaran akan pentingnya persatuan dan kesatuan, gotong-royong, toleransi, taat pada agama dan kepercayaan, 
adanya jiwa patriotisme yang tinggi, perlu di aktualisasikan dan direvitalisasikan.

- Banyaknya peninggalan arkeologi yang terdapat diseluruh wilayah Maluku, merupakan sebuah sumberdaya yang sangat potensial dan perlu dikembangkan dan dimanfaatkan, untuk berbagai kepentingan yang dapat meningkatkan taraf hidup masyarakat.

\section{Saran-saran}

Mengingat bahwa sumberdaya arkeologi yang dimiliki sifatnya sangat terbatas dan unik, dan sering terjadinya perbuatan yang dapat menghilangkan dan mengurangi kwalitas dan kwantitas berbagai sumberdaya arkeologi, yang berarti turut hilangnya berbagai konsep / nilai luhur yang ada didalamnya, maka beberapa hal yang disarankan adalah :

- Pemerintah Daerah sebagai pengelola kebudayaan (benda budaya dan nilai budaya) perlu segera melakukan sosialisasi kepada masyarakat bahwa sesungguhnya kebudayaan tersebut adalah miliki masyarakat. Caranya adalah melibatkan secara langsung msyarakat dalam berbagai upaya pengembangan kebudayaan.

- Mengangkat / menampilkan kembali nilai-nilai luhur budaya masyarakat Maluku, yang dahulu terkenal sangat berjaya dalam hal toleran dalam kehidupan bermasyarakat, dan menjadi contoh yang sangat baik di dunia.

- Meningkatkan perhatian kepada masalah-masalah kebudayaan, sehinga masyarakat Maluku tetap mengetahui dan memahami kebudayaan (benda budaya dan nilai budaya) leluhur, sehingga dalam dinamika kehidupan masa kini dan masa yang akan datang tetap berdiri diatas akar budaya Maluku sendiri.

\section{DAFTAR PUSTAKA}

Ambary, Hasan, Muarif, 1994

Laporan, PenelitianArkeologi,IslamTernate, Kecamatan Ternate, Maluku Utara.Balar Ambon (tt) 1995.

Penelitian Arkeologi IslamTernate, BacanJailolo, Maluku Utara. Balar Ambon (tt).

Cleere, Henry, 1984.

World Cultural Resource Management Problems and Perspective. Dalam Aproaches the Archaeological Heritage. Canbridge University Press

Gimsey, MC. III. Charles, R, 1972. Public Archaeology. New York Seminar Press

Heekern, H.R.van,1958. The Bronze Iron Age of Indonesia. VKI. XXII, S.Gravenhage - 1972.

The Stone Age of Indonesia. The Hague Martinus

Intan S. Fadhlan M dan Istari Rita T.M, 1996, Geologi dan Arkeologi Situs Gua Kei Kecil, Maluku Tenggara, Bagian proyek penelitian Purbakala Maluku

Jonge de Nico \& Toos van Dijk.1995. Forgotten Islands of Indonesia,Periplus

Kempers,DR.A.J.Bernet.1959. Ancient Indonesian Arts. Amsterdam

Koentjaraningrat.1958.

Metode-metode antropologi dalam penelitian penyelidikan masyarakat dan kebudayaan di Indonesia.penerbitan universitas jakarta.

Koentjaraningrat,1979.

Pengantar ilmu antropologi. Aksara Baru Jakarta

Nendisa, Drs, M. 1997.

Laporan Hasil Penelitian Arkeologi Kolonial Maluku Situs Lonthor, Kecamatan Banda Naira,Maluku Tengah. Balai Ark ologi Ambon (TT).

Kapata Arkeologi Vol. 2 No. 3 November 2006 Balai Arkeologi Ambon 
Perry, W.J. 1918.

Megalithic Culture in Indonesia,Menchester the University Press

Rijoly, Drs Frans, 1989.

Guide Books Indonesia- English Edition Siwalima Ambon. Proyek Pembinaan Permuseuman Maluku.

Sahusilawane, Dra, F. 1996a.

Laporan Penelitian Arkeologi Islam Maluku. Situs Iha, Kecamatan

Saparus, Maluku Tengah. Balai Arkeologi Ambon (TT). .1996b.

Laporan Hasil Penelitian Arkeologi Klasik, Kec. Kei Besar, Kabupaten Maluku Tenggara. Balai Arkeologi Ambon (TT). . 1996c.

Laporan penelitian Arkeologi Klasik, Kec. Kei Kecil, Kabupaten Maluku Tenggara.Balai Arkeologi Ambon(TT)

Soejono, R.P. 1972.

Prasejarah Maluku, Seminar Sejarah Maluku I Ambon.

Soejono, 1984.

Sejarah Nasional Indonesia I. P N Balai Pustaka.Jakarta

Soekmono, 1982.

Pengantar Sejarah Kebudayaan Indonesia. Jilid IIYayasan Kanisius, Yogyakarta

Sudarmika, Drs, G.M. 2000.

Laporan Penelitian Arkeologi di Kepulauan Tanimbarkei, Kecamatan Kei Kecil, Maluku Tenggara. Balai Arkeologi Ambon (TT

-------,,----------- 2001.

Laporan Penelitian Arkeologi di Pulau Lakor, Kecamatan Leti Moa Lakor, Maluku Tenggara. Balai Arkeologi Ambon (TT).

Sumadio, Bambang. 1984.

Sejarah Nasional Indonesia II. PN. Balai PustakaJakarta

Suryanto, Drs, Diman. 1997.

Laporan Penelitian Arkeologi. Situs Wamkana, Kecamatan Buru Selatan, Maluku Tengah. Balai Arkeologi Ambon 